
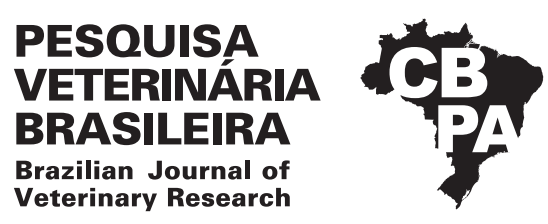

Pesq. Vet. Bras. 38(7):1365-1370, julho 2018 DOI: $10.1590 / 1678-5150-P V B-5643$

Original Article

ISSN 0100-736X (Print)

ISSN 1678-5150 (Online)

\title{
Economic impact of an outbreak of botulism in a cattle feedlot ${ }^{1}$
}

\author{
Marcelo Cezar Soares ${ }^{2}$, Alberto O. Gaspar², Ricardo C. Brumatti², Danilo C. Gomes², \\ Daniela A. Neves ${ }^{3}$, Lilian O.B. Alcântara ${ }^{3}$, Paula V. Leal ${ }^{2}$ and Ricardo A.A. Lemos²*
}

\begin{abstract}
Soares M.C., Gaspar A.O., Brumatti R.C., Gomes D.C., Neves D.A., Alcântara L.O.B., Leal P.V. \& Lemos R.A.A. 2018. Economic impact of an outbreak of botulism in a cattle feedlot. Pesquisa Veterinária Brasileira 38(7):1365-1370. Faculdade de Medicina Veterinária e Zootecnia, Universidade Federal de Mato Grosso do Sul, Avenida Senador Felinto Müller 2443, Jardim Parati, Campo Grande, MS 79070-900, Brazil. E-mail: marcelocezar@outlook.com

Botulism is a febrile disease, fatal in most cases, which affects the muscles of locomotion, chewing, and swallowing, as well as the diaphragm and intercostal muscles, causing flaccid paralysis and respiratory arrest. In bovines, the etiology is due to the ingestion of neurotoxins types $\mathrm{C}$ and $\mathrm{D}$ formed by the bacterium Clostridium botulinum in an animal or vegetal substance, during decomposition. Vaccination is one of the most effective prophylactic means to prevent this disease. In this study, an outbreak of botulism was evaluated in a feedlot with 6,300 finishing cattle, wherein 25 died as a consequence of contracting this disease. The economic losses resulting from the deaths were analyzed, and economic analysis was conducted, involving the estimated cost of vaccination for the whole herd under risk, with the objective of evaluating whether this prophylactic practice is a viable action plan. The financial loss due to the deaths resulting from botulism in the case studied was found to be $\mathrm{R} \$ 55,560.00$, equivalent to $0.39 \%$ of the total monetary value of the herd. The cost of immunizing the entire herd under risk was $14.06 \%$ (for toxins exclusive to toxins C and D) and $22.22 \%$ (for polyvalent vaccines against clostridiosis) of the financial loss incurred as a consequence of the recorded deaths. It was concluded that botulism is a disease that can cause a significant economic impact on intensive livestock production systems, and that vaccination is an economically viable prophylactic action if performed with adequate sanitary planning.
\end{abstract}

INDEX TERMS: Economic impact, outbreak of botulism, cattle, feedlot, economic analysis, vaccination, pathology.

\begin{abstract}
RESUMO.- [Impacto econômico de um surto de botulismo em confinamento de bovinos.] 0 botulismo é uma doença afebril, fatal na maioria dos casos, que afeta os músculos da locomoção, mastigação, deglutição e também o diafragma e os músculos intercostais, causando paralisia flácida e parada respiratória. Nos bovinos a etiologia é devido à ingestão de neurotoxinas tipos C e D previamente formadas pela bactéria Clostridium botulinum em matéria animal ou vegetal em decomposição. A vacinação é um dos meios profiláticos
\end{abstract}

\footnotetext{
${ }^{1}$ Received on January 23, 2018.

Accept for publication on February 6, 2018.

${ }^{2}$ Faculdade de Medicina Veterinária e Zootecnia (FAMEZ), Universidade Federal de Mato Grosso do Sul (UFMS), Av. Senador Felinto Müller 2443, Jardim Parati, Campo Grande, MS 79070-900, Brazil.

${ }^{3}$ Agência Estadual de Defesa Sanitária Animal e Vegetal (Iagro/MS), Av. Senador Felinto Müller 1146, Jardim Parati, Campo Grande, MS 79074-460. *Corresponding author: ricardo.lemos@ufms.br
}

mais eficazes para prevenir esta doença. Neste trabalho, estudou-se um surto de botulismo em um confinamento com 6300 bovinos em terminação, no qual 25 morreram devido a esta doença. Foram analisadas as perdas econômicas em consequência das mortes, e por meio do percentual do prejuízo contabilizado, foi realizada uma análise econômica referente ao custo estimado da vacinação para todo do rebanho sob-risco com o objetivo de avaliar se esta prática profilática é um plano de ação viável. Como resultado, o prejuízo financeiro devido às mortes resultantes do botulismo no caso estudado foi de $\mathrm{R} \$ 55.560,00$ o equivalente a $0,39 \%$ do valor monetário total do rebanho. 0 custo da vacinação para imunizar todo o rebanho sob-risco foi equivalente a $14,06 \%$ (para vacinas exclusivas para toxinas C e D) e $22,22 \%$ (para vacinas polivalentes contra clostridioses) relativo ao prejuízo financeiro em consequência dos óbitos registrados. Concluiu-se que o botulismo é uma doença que 
pode provocar impacto econômico significativo em sistemas de corte intensivos em bovinos, e que, a vacinação é um meio profilático economicamente viável se for realizada por meio de um planejamento sanitário adequado.

TERMOS DE INDEXAÇÃO: Impacto econômico, botulismo, confinamento de bovinos, doenças de bovinos, análise econômica, vacinação, patologia.

\section{INTRODUCTION}

Botulism is a disease that impacts humans and animals alike, affecting the muscles of locomotion, chewing, swallowing, and breathing, and ultimately resulting in a progression to flaccid paralysis and respiratory arrest (Kriek \& Ondendaal 1994, Hogg et al. 2008, Maréchal et al. 2016). It is considered a non-febrile and highly fatal intoxication, usually caused by the ingestion of botulinum toxins present in decomposing organic matter, which is usually of animal origin but can also be present in vegetable matter (Colbachini et al. 1999, Tavella et al. 2014).

The occurrence of the disease is mainly related to two factors: the sensitivity of the animal species and the type and amount of botulinum toxin ingested. There are seven types of botulinum toxins (A to $G$ ) that, though antigenically distinct from each other, demonstrate similar modes of action in the affected animal (Maréchal et al. 2016). The toxins are absorbed and transported to sensitive neurons via the blood, where they then act at neuromuscular junctions, resulting in motor paralysis without interference in functional sensory function. Primarily, the toxins affect the peripheral nervous system, where they block the process of synapse release of acetylcholine, which prevents the passage of nerve impulses to the muscle, causing flaccid paralysis. (Kriek \& Ondendaal 1994, Num \& Useh 2014, Maréchal et al. 2016). In humans, most cases of botulism are caused by toxins type A, B, E, and sometimes-though rarely-by $\mathrm{F}$, while in cattle, botulism is caused by the ingestion of neurotoxins types $C$ and $D$ previously formed by Clostridium botulinum in decomposed animal or vegetable matter (Maréchal et al. 2016).

Cases of botulism in cattle have been described in several countries of the world (WHO 2002, Lindström et al. 2010), predominantly resulting from ingestion of the toxin in contaminated food or water, or by osteopathy practiced in animals. In European countries, Brazil, South Africa, Australia, and the Gulf Coast region of the United States, where phosphorus deficiency is a common condition, osteophagia is the main risk factor for the occurrence of the disease in extensive farming systems (Radostits 2001, Cameron 2009, Num \& Useh 2014). Other scenarios such as ingestion of water in the presence of carcasses of animals or the consumption of cereals such as corn, hay, and silage wrongly conserved or that contain the remains of carcasses of animals have also been described as factors leading to onset (Galey et al. 2000, Kelch et al. 2000, Dutra et al. 2005, Lobato et al. 2008, Maboni et al. 2010). Although the disease is considered one of the main causes of mortality in cattle raised extensively in Brazil (Döbereiner et al. 1992), the true reality of the effects of this disease in Brazil is not very well-reported, because reports of outbreaks in intensive breeding systems are scarce, although animals in feedlots are also susceptible to botulinum toxicity due to the risk of intoxication through contaminated, wrongly conserved feed containing decomposed organic matter or small corpses that generate ideal conditions for bacterial multiplication and toxin production (Galey et al. 2000, Dutra et al. 2005, Maboni et al. 2010).

The conduction of economic analysis research with respect to animal health is a sector that is growing and that has become increasingly important because it is a major source of information that can assist in the making of decisions to improve the management of the health of the herd, with the aim of making the production system increasingly sustainable and economically viable. Moreover, it is a valuable tool to make any activity in the integrated agribusiness sector in the socio-economic dynamics, improving the profitability of activities and consequently ensuring better social and economic development (Dijkhuizen et al. 1995, Rich \& Perry 2011).

The objective of the current study was to describe the economic impact of an outbreak of botulism in feedlot cattle and to also elucidate the diagnostic and health measures needed to minimize or avoid losses caused by this disease.

\section{MATERIALS AND METHODS}

Epidemiological, clinical, and management information was obtained through inspection visits conducted at the outbreak site and via structured interviews so that the owner was able to relay entire production process and any other relevant information that could help in the diagnosis of outbreaks and calculated economic analyses.

The initial clinical signs included the presence of locomotor difficulty without compromise of the mental state, and progressive flaccid paralysis of the muscles, mainly the pelvic area. Sternal recumbency and after wing were also used as criteria for diagnosis. Another clinical sign strongly indicative of the disease was the presence of respiratory difficulty characterized by biphasic inspiration breathing, with an initial rapid attempt to distend the thorax, followed by another prolonged and difficult phase aided by the diaphragm (Barros et al. 2006).

Clinical examination followed by necropsy was performed in six cattle, of which two died spontaneously and four were euthanized in the terminal phase. From the necropsied bovines, samples of different organs were collected and fixed in $10 \%$ formalin, and later processed for histology results. Fragments of the central nervous system were kept under refrigeration and examined for rabies. Samples of the ruminal, liver and intestinal contents were collected from the six necropsied animals and kept under refrigeration until they were subjected to toxicological examination for botulinum toxin types $\mathrm{C}$ and $\mathrm{D}$, according to the recommendations described by Dowell \& Hawkins (1987).

The evaluation of the economic impact was based on the number of cattle on the risk-containment and the number of dead animals, respectively. In order to estimate the monetary value of each animal, the value paid to producers $(\mathrm{R} \$ / \mathrm{kg})$ for finished cattle in the period when the outbreak occurred, based on the average live weight of the animals in the place studied, was obtained from the Center for Advanced Studies in Applied Economics (CEPEA/Esalq).

To evaluate the prophylactic costs of a vaccination program, two types of vaccines that have been quoted in the local market, a vaccine containing butolinic toxoids $C$ and $D$, and another polyvalent vaccine with toxoids and bacterin for other clostridial diseases, were considered. The following values were calculated:

$$
\text { Vun }=(\mathrm{PV} \times \text { Rend }) \times \mathrm{Pkg}
$$

Where Vun is the unit monetary value of the reported animal category; PV is the mean live weight of the at-risk animals; Rend is the estimated carcass yield; and $\mathrm{Pkg}$ is the average price paid per $\mathrm{kg}$ to the producer at the time of the outbreak. 


$$
\mathrm{Vt}=\mathrm{Qr} \times \operatorname{Vun}
$$

Where Vt is the total monetary value of the herd under risk; Qr is the total number of cattle in the herd under risk; and Vun is the unit monetary value of the reported animal category.

$$
\mathrm{Pt}=\mathrm{Qm} \times \text { Vun }
$$

Where Pt is the total economic loss related to the deaths; Qm is the the number of animals who died due to botulism; and Vun is the unit monetary value of the reported animal category.

$$
\mathrm{Pj}=(\mathrm{Pt} / \mathrm{Vt}) \times 100
$$

Where $\mathrm{Pj}$ is the percentage of estimated economic loss; $\mathrm{Pt}$ is the total economic loss related to the deaths; and $\mathrm{Vt}$ is the total monetary value of the herd under risk.

$$
\mathrm{Vcv}=\mathrm{Qr} \times \mathrm{Vuv}
$$

Where Vcv is the value of the estimated cost of vaccination; $\mathrm{Qr}$ is the total amount of cattle in the herd at-risk; and Vuv is the unit monetary value (cost) of vaccination per animal.

$$
\mathrm{IcvP}=(\mathrm{Vcv} / \mathrm{Pt}) \times 100
$$

Where IcvP is the determination of the impact of vaccination cost on injury; $\mathrm{Vcv}$ is the value of the estimated cost with vaccination; and $\mathrm{Pt}$ is the total economic loss related to the deaths.

\section{RESULTS}

The outbreak of botulism occurred in August 2016 in an intensive system of rigorous fattening (cattle feedlot) in which there were 6.300 cattle, half of whom had come from the property itself and the other half of whom were purchases from other rural properties. Most of the purchased cattle were males aged between 18 and 24 months with approximately $480 \mathrm{~kg}$ of live weight. In the feedlot, the animals were dispersed among 28 lots, with each containing approximately 225 animals. The dietary management regimen of the cattle consisted of three phases: an initial phase adjustment period for 14 days, in which the feed consisted of $50 \%$ concentrate and $50 \%$ forage, then a seven-day a composite intermediate diet comprised $60 \%$ of concentrate and $40 \%$ of forage; and lastly a final phase in which the animals received a finishing diet consisting of $80 \%$ concentrate and $20 \%$ forage for 90 days, totaling a confinement period of approximately 110 to 120 days. The concentrate used was basically corn, soybean, and cottonseed, and the forage used was Brachiaria brizantha hay. The cases started ten days after the replacement of the hay originally used by another of the same forage; the replacement occurred because the original hay was stored wrongly, in that it was unprotected and exposed to rains for a period of 10 months. Twenty-five cattle from seven different lots, all born on the farm, became ill and died. The cattle who were subjected to physical examinations presented with good body condition but showed similar signs, with a clinical evolution ranging from two to seven days, characterized by motor incoordination followed by sternal decubitus, and when stimulated to stand up, they made unsuccessful attempts. A reduction of the muscle tone of the mandible and tongue was present in all of the cattle examined. No animal had altered mental status or loss of sensitivity, and all had dyspnea and difficult abdominal breathing. The condition progressed to lateral decubitus followed by death.

No macroscopic or histological changes were observed in the collected necropsied bovine material. The presence of botulinum toxin type $C$ in one of the necropsied cattle and the presence of botulinum toxin type $\mathrm{D}$ in another bovine were detected through the toxicological test for botulinum toxin using a bioassay technique followed by seroneutralization, previously used in mice. All materials submitted for rabies diagnosis yielded negative results.

In relation to the prophylactic health management concept related to the use of vaccines, all the animals were submitted to vaccination against foot-and-mouth disease according to the official calendar and also against rabies (with the first dose administered at four months of age with a booster administered 30 days after primovaccination, and then annually). However, only the animals purchased were immunized with botulinum toxoids type $C$ and $D$.

The new hay feed introduced 10 days before the start of the outbreak had mold and decomposition characteristics, the result of improper storage and exposure to the environment over a period of 10 months. After the first cases appeared, this hay was removed from the feed and replaced with another of good quality produced in the current rural property. Cases of the disease occurred up to 18 days after hay replacement.

According to quotations from the Finishing Cattle Indicator CEPEA/Esalq, the average price paid to the producer at the time of the outbreak was $\mathrm{R} \$ 9.26 / \mathrm{kg}$, and the average monetary value estimated per bovine was $\mathrm{R} \$ 2,222.40$, considering an average carcass yield of 50\% as recommended by Peripolli et al. (2016).

Regarding the average cost of vaccination in the budget survey, the average dose of the exclusive vaccine for botulinum toxins was $\mathrm{R} \$ 0.62$, and the average dose for the polyvalent vaccine against clostridial diseases was $\mathrm{R} \$ 0.98$.

The economic calculations performed in this study, which include the total monetary value representing the at-risk herd, the monetary value measured with the deaths, the estimated

\begin{tabular}{|c|c|}
\hline Economic data reviewed & Results $^{* *}$ \\
\hline Total monetary value of the at-risk herd (6,300 animals) & $\mathrm{R} \$ 14,001,120.00$ \\
\hline Total economic loss related to botulism deaths (25 deaths) & $\mathrm{R} \$ 55,560.00$ \\
\hline Percentage of injury estimated as deaths in relation to the total monetary value of the herd of cattle feedlot & $0.39 \%$ \\
\hline Estimated cost of vaccination/year (polyvalent clostridial vaccine), considering two doses of vaccine/animal* & $\mathrm{R} \$ 12,348.00$ \\
\hline Estimated cost of vaccination/year (vaccine only for botulism), considering two doses of vaccine/animal & $\mathrm{R} \$ 7,812.00$ \\
\hline Impact of the cost of vaccination (polyvalent clostridial vaccine) on the economic loss caused by botulism deaths & $22.22 \%$ \\
\hline Impact of the cost of vaccination (vaccine only for botulism) on the economic loss caused by botulism deaths & $14.06 \%$ \\
\hline
\end{tabular}
economic loss percentage, the relative cost of vaccination for cattle, and the impact of the cost of vaccination on the economic loss, are shown in Table 1.

Table 1. Results of the economic evaluation of the outbreak of botulism in the cattle feedlot

* According to the protocol two applications of the vaccine are necessary, and the second dose should be applied on average four to six weeks after primovaccination. ** Reference value: US\$3,202 according to the Central Bank of Brazil (Aug/2016). 
In the studied outbreak, the mortality resulting from outbreaks of botulism resulted in $0.39 \%$ of the total herd at-risk in the confinement being affected, as a consequence of the consumption of hay contaminated with the botulinum toxin. The economic loss related to the deaths during the outbreak period was $\mathrm{R} \$ 55,560.40$, representing an estimated injury percentage of close to $0.39 \%$ of the total monetary value of the herd.

\section{DISCUSSION}

The diagnosis of botulism was made based on epidemiological evidence (ingestion of decomposing hay), clinical signs, the absence of significant macro and microscopic lesions, the elimination of other possible causes of the signs presented, and confirmation of botulinum toxin in the organs from the necropsied cattle. The detection of botulinum toxin in liver, ruminal contents or bovine intestinal samples is a gold standard for the confirmation of the disease's diagnosis. However, a negative result obtained using the tests of bioassay and seroneutralization done in mice does not exclude the possibility of botulism, since the levels of botulinum toxin in the animals may be below the threshold for detection through the test (Menegucci et al. 1998, Dutra 2001, Heider et al. 2001). It is possible realize a presumptive diagnosis of botulism when botulinum toxin is not detected in bovine organ samples due to clinical signs such as consistent disease, ingestion of evidence of the toxin by cattle, and by eliminating other possible causes of similar clinical manifestations to botulism, such as other diseases that affect the nervous system (Silva et al. 2016).

The differential diagnosis includes other diseases that cause neurological disorders, among which are rabies (Oliveira et al. 2012), listeriosis (Rissi et al. 2010), organophosphate poisoning (Castro et al. 2007), mycotoxin poisoning produced by the fungus Aspergillus clavatus (Loretti et al. 2003), and polioencephalomalacia (Sampaio et al.2015). Diseases affecting the musculoskeletal system such as poisoning by plants of the genus Senna sp. (Carvalho et al. 2014), ionophores antibiotics (Nogueira et al. 2009), and hepatic encephalopathy stemming from intoxication by Crotalaria sp. (Anjos et al. 2010), should also be considered among the differential diagnosis.

Based on epidemiological evidence and the findings of inadequate characteristics of the hay used in the diet of animals, the hay was considered as the source of botulinum toxin; thus, 6,300 animals were at-risk at the cattle feedlot, because all animals received the same diet. The morbidity coefficient was $0.39 \%$ (25/6300) and the lethality coefficient was $100 \%$. It is important to emphasize that the morbidity and lethality coefficients involving botulism outbreaks are highly variable, since the impacts caused by this disease depend on many factors such as the amount, concentration, and period of ingestion of the neurotoxin consumed by the animals (Colbachini et al. 1999). In other botulism outbreaks in confined animals, the morbidity rate was varied: for example, in animals infected with corn silage, a $6.81 \%$ rate was observed; while in another study evaluating 1,087 animals confirmed to be at-risk who were receiving contaminated maize, the average coefficient morbidity was close to $29.34 \%$ (Dutra 2001); and in confined animals receiving poultry litter, the variation in morbidity was from $3.43 \%$ to $100 \%$ (Dutra et al. 2005). However, the high lethality coefficient of $100 \%$ observed in the outbreak analyzed in this current study corroborates with the findings of several other outbreaks evaluated (Dutra 2001, Dutra et al. 2005, Costa et al. 2008, Tavella et al. 2014).

When analyzing sanitary indicators, such as the absence of vaccination in conjunction with inadequate feed conservation, the risks for botulism in the herd increase considerably and consequently cause significant economic losses (Barros et al. 2006, Cursi et al. 2013). These two conditions occurred in the outbreak studied. The use of vaccine protection against botulism can be very effective, however, some factors can minimize this efficiency, such as the amount of ingested dose of the neurotoxin, because even animals who are vaccinated may develop the disease if exposed to large enough amounts of it, or when the source of the toxin is not identified and removed from the area, keeping the animals exposed to the potential for ingesting it (Steinman et al. 2007).

When vaccination of the herd with bivalent toxoids $\mathrm{C}$ and $\mathrm{D}$ is carried out in conjunction with a reduction in the exposure of the bovine to botulinum neurotoxin, then the rate of protection against the disease may reach 96\% (Cursi et al. 2013). For this, we recommend the protocol of vaccination with two doses, the primovaccination followed by booster vaccination between four to six weeks (Gaspar et al. 2015). For vaccines with bivalent toxoids $C$ and $D$, according to the protocol of vaccination in which each animal receives two doses, through the budget research done in the local market, the average cost/animal of the calculated vaccination was $\mathrm{R} \$ 1.24$ (1 Brazil real and 24 US cents). In the cattle feedlot studied, there were 6,300 animals. In order to immunize all cattle in the herd who are at-risk, the total cost would be $\mathrm{R} \$ 7,812.00$; that is, the cost of vaccination would represent $14.06 \%$ of the total economic loss due to the deaths ( $\mathrm{R} \$ 55,560.00)$, or, to vaccinate the entire herd, the cost of the vaccine would be equivalent to 3.51 animals with a unit monetary value of $\mathrm{R} \$ 2,222.40$.

Considering that in cattle feedlots, there are risk conditions for the occurrence of other clostridioses diseases (Rezende et al. 2014), the use of polyvalent vaccines can be considered as a better strategy from the point of view of the sanitary management of the animals. According to the local budget research, the dose of the polyvalent vaccine against clostridiosis was, on average, $\mathrm{R} \$ 0.98$ and, according to the vaccination protocol recommended by Gaspar et al. (2015) for providing efficient immunological protection to animals, it is necessary to perform two doses/animal, resulting in a total vaccination/animal cost of $\mathrm{R} \$ 1.96$. Totaling the amount of the estimated cost of vaccination against clostridial diseases in the studied herd, the total cost of vaccination would be $\mathrm{R} \$ 12,348.00$. This amount would represent $22.22 \%$ of the total economic loss measured by the deaths; that is, to vaccinate the entire herd at risk, the cost of the vaccine would be 5.55 animals from the herd studied. So, even the polyvalent vaccine, with a cost of $36.74 \%$ more than the vaccine that would protect the herd only against botulism, is economically viable, considering the losses caused by the deaths of animals in the feedlot studied in this work, and the risk of other clostridioses diseases occurring. It is important to note that although the vaccination of cattle against botulism, both in intensive systems such as in extensive systems as a recommended prophylactic sanitary measure (Anniballi et al. 2013, Cursi et al. 2013) and also as an economically viable option with regards to mitigating the economic losses that botulism generated in the present 
case, under the conditions in which the outbreak of this study occurred, this procedure would not be recommended after the appearance of clinical cases. The proper explanation for this is that, firstly, the exposed cattle are already predisposed to the action of the botulinum neurotoxin, and the vaccine only has a preventive effect and not a therapeutic effect in animals already intoxicated (Steinman et al. 2006). Another factor is that the period required for the vaccine to stimulate an effective immune response involving the formation of antibodies against botulism is 30 days after primovaccination, on the second dose application (Riet-Correa 2007, Cursi et al. 2013), and in the case evaluated in this study, the outbreaks occurred 70 days after the cattle entered in the feedlot. With that period, the establishment of immunity would coincide with the date of the outgoing of the animals for slaughter, thus making vaccination as a strategic procedure not feasible, in the specific case in the evaluated outbreak.

Under conditions similar to the present outbreak, the best conduit for containment of this disease is to immediately identify and withdraw the feed in which the botulinum neurotoxin is present. It is important to note that new cases may occur up to 18 days after the removal of contaminated feed. In this way, vaccination can be considered a viable prophylactic, sanitary, and economical option. However, adequate sanitary schedule and planning is necessary for its execution, considering the risks and the time necessary for the cattle to acquire adequate immunological protection.

\section{CONCLUSIONS}

Botulism can cause potential economic losses in cattle feedlots, and vaccination is a recommended and economically feasible prophylactic measure in these production systems if performed correctly.

The most effective measure is the use of feed not contaminated with botulinum neurotoxin.

In outbreaks of botulism, the immediate removal of the source of the toxin is necessary.

Acknowledgements.- This work was funded by the FUNDECT/CNPq - Grant 15/2014, PRONEM-MS - Grant 59/300.126/2015, FUNDECT/CAPES 05/2014 and by PPVMS - Grant 59/300.032/2015.

\section{REFERENCES}

Anniballi F., Fiore A., Löfström C., Skarin H., Auricchio B., Woudstra C., Bano L., Segerman B., Koene M., Båverud V., Hansen T., Fach P., Tevell Aberg A., Hedeland M., Olsson Engvall E. \& De Medici D. 2013. Management of animal botulism outbreaks: from clinical suspicion to practical countermeasures to prevent or minimize outbreaks. Biosecurity Bioterrorism 35(Suppl. 1):5191-5199. $<$ PMid:23971806>

Anjos B.L., Nobre V.M.T., Dantas A.F.M., Medeiros R.M.T., Oliveira Neto T.S., Molyneux R.J. \& Riet-Correa F. 2010. Poisoning of sheep by seeds of Crotalaria retusa: acquired resistance by continuous administration of low doses. Toxicon 55(1):28-32. <http://dx.doi.org/10.1016/j.toxicon.2009.06.028> $<$ PMid:19576921>

Barros C.S.L., Driemeier D., Dutra I.S. \& Lemos R.A.A. 2006. Doenças do Sistema Nervoso de Bovinos no Brasil. Agnes Gráfica e Editora, São Paulo. 207p.

Cameron C.M. 2009. A brief history of botulism in South Africa. Onderstepoort J. Vet. Res. 76(1):11-12. <http://dx.doi.org/10.4102/ojvr.v76i1.54> <PMid:19967922>
Carvalho A.Q., Carvalho N.M., Vieira G.P., Santos A.C., Franco G.L., Pott A., Barros C.S.L. \& Lemos R.A.A. 2014. Intoxicação espontânea por Senna obtusifolia em bovinos no Pantanal Sul-Mato-Grossense. Pesq. Vet. Bras. 34(2):147-152. <http://dx.doi.org/10.1590/S0100-736X2014000200009>

Castro M.B., Moscardini A.R.C., Reis Junior J.L., Novaes E.P.F. \& Borges J.R.J. 2007. Intoxicação aguda por diazinon em bovinos. Ciência Rural 37(5):14981501. <http://dx.doi.org/10.1590/S0103-84782007000500049>

Colbachini L., Schocken-Iturrino R.P. \& Marquez L.C. 1999. Intoxicação experimental de bovinos com toxina botulínica tipo D. Arq. Bras. Med. Vet. Zootec. 51(3):229-234. <http://dx.doi.org/10.1590/S010209351999000300005>

Costa G.M., Salvador S.C. \& Pereira M.N. 2008. Botulismo em bovinos leiteiros no sul de Minas Gerais, Brasil. Ciência Rural 38(7):2068-2071. <http:// dx.doi.org/10.1590/S0103-84782008000700045>

Cursi V.C.M., Zocoller-Seno M.C., Nogueira A.H.C., Araujo R.F., Cardoso T.C. \& Dutra I.S. 2013. Resposta humoral de bovinos vacinados contra as toxinas botulínicas tipos C e D em diferentes faixas etárias. Arqs Inst. Biológico, São Paulo, 80(1):99-102.

Dijkhuizen A.A., Huirne R.B.M. \& Jalvingh A.W. 1995. Economic analysis of animal diseases and their control. Prev. Vet. Med. 25(2):135-149. <http:// dx.doi.org/10.1016/0167-5877(95)00535-8>

Döbereiner J., Tokarnia C.H., Langenegger J. \& Dutra I.S. 1992. Epizootic botulism of cattle in Brazil. Dtsch. Tierärztl. Wochenschr. 99(5):188-190. $<$ PMid:1638962>

Dowell I.S. \& Hawkins T.M. 1987. Laboratory Methods in Anaerobic Bacteriology: CDC Laboratory Manual. U.S. Department of Health and Human Services, Atlanta, Georgia, p.41-44.

Dutra I.S. 2001. Epidemiologia, quadro clínico e diagnóstico pela soroneutralização em camundongos do botulismo em bovinos no Brasil (1989-2001). Tese de Livre-Docência no Curso de Medicina Veterinária, Universidade Estadual Paulista, Campus de Araçatuba. 133p.

Dutra I.S., Döbereiner J. \& Souza A.M. 2005. Botulismo em bovinos de corte e leite alimentados com cama de frango. Pesq. Vet. Bras. 25(2):115-119. <http://dx.doi.org/10.1590/S0100-736X2005000200009>

Galey F.D., Terra R., Walker R., Adaska J., Etchebarne M.A., Puschner B., Fisher E., Whitlock R.H., Rocke T., Willoughby D. \& Tor E. 2000. Type C botulism in dairy cattle from feed contaminated with a dead cat. J. Vet. Diagn. Invest. 12(3):204-209. <http://dx.doi.org/10.1177/104063870001200302> $<$ PMid:10826832>

Gaspar E.B., Minho A.P. \& Santos L.R. 2015. Manual de boas práticas de vacinação e imunização de bovinos. Circ. Téc. 47, Embrapa Pecuária Sul, Bagé, RS. 8p.

Heider L.C., McClure J.T. \& Leger E.R. 2001. Presumptive diagnosis of Clostridium botulinum type D intoxication in a heard of feedlot cattle. Can. Vet. J. 42(3):2010-2012. <PMid:11265191>

Hogg R., Livesey C. \& Payne J. 2008. Diagnosis and implications of botulism. In Pract. 30(7):392-397. <http://dx.doi.org/10.1136/inpract.30.7.392>

Kelch W.J., Kerr L.A., Pringle J.K., Rohrbach B.W. \& Whitlock R.H. 2000. Fatal Clostridium botulinum toxicosis in eleven Holstein cattle fed round bale barley haylage. J. Vet. Diagn. Invest. 12(5):453-455. <http://dx.doi. org/10.1177/104063870001200511><PMid:11021434>

Kriek N.P.J. \& Odendaal M.W. 1994. Botulism, p.1354-1371. In: Coetzer J.A.W., Thomson G.R. \& Tustin R.C. (Eds), Infectious Diseases of Livestock. Oxford Press, Cape Town.

Lindström M., Myllykoski J., Sivelä S. \& Korkeala H. 2010. Clostridium botulinum in cattle and dairy products. Crit. Rev. Food Sci. Nutr. 50(4):281-304. <http://dx.doi.org/10.1080/10408390802544405> <PMid:20301016>

Lobato C.F., Salvarani F.M., Silva R.O.S., Souza A.M., Lima C.G.R.D., Pires P.S., Assis R.A. \& Azevedo E.0. 2008. Botulismo em ruminantes causado pela 
ingestão de cama-de-frango. Ciência Rural 38(4):1176-1178. <http:// dx.doi.org/10.1590/S0103-84782008000400046>

Loretti A.P., Colodel E.M., Driemeier D., Corrêa A.M., Bangel Junior J.J. \& Ferreiro L. 2003. Neurological disorder in dairy cattle associated with consumption of beer residues contaminated with Aspergillus clavatus. J. Vet. Diagn. Invest. 15(2):123-132. <http://dx.doi.org/10.1177/104063870301500206> $<$ PMid:12661722>

Maboni F., Monego F., Matiuzzi da Costa M., Dutra I. \& Palmira Castagna de Vargas A. 2010. Ocorrência de botulismo em bovinos confinados no Rio Grande do Sul. Ciênc. Anim. Bras. 11(4):962-965. <http://dx.doi. org/10.5216/cab.v11i4.3336>

Maréchal C.L., Woudstra C. \& Fach P. 2016. Botulism, p.303-330. In: Uzal F.A., Songer G., Prescott J.F. \& Popoff M.R. (Eds), Clostridial Diseases of Animals. Wiley Blackwell. <http://dx.doi.org/10.1002/9781118728291.ch26>.

Menegucci E.A., Dutra I.S. \& Döbereiner J. 1998. Sensibilidade toxicológica e especificidade do teste de microfixação de complemento na detecção de toxinas botulínicas C e D em meio de cultura e fígado de camundongos. Pesq. Vet. Bras. 18(2):47-52. <http://dx.doi.org/10.1590/S0100736X1998000200001>

Nogueira V.A., França T.N. \& Peixoto P.V. 2009. Intoxicação por antibióticos ionóforos em animais. Pesq. Vet. Bras. 29(3):191-197. <http://dx.doi. org/10.1590/S0100-736X2009000300001>

Num S.M. \& Useh N.M. 2014. Botulism in man and animals. Bulg. J. Vet. Med. 17(4):241-266.

Oliveira T.S., Bull V., Rezende C.A., Furtini R., Costa E.A., Paixão T.A. \& Santos R.L. 2012. Perfil das amostras do sistema nervoso central de bovinos com síndrome neurológica e diagnóstico da raiva bovina no serviço de defesa sanitária de Minas Gerais (2003-2010). Pesq. Vet. Bras. 32(4):333-339. <http://dx.doi.org/10.1590/S0100-736X2012000400010>

Peripolli E., Oliveira M.S.L., Baldi F., Pereira A.S.C., Vercesi A.E. \& Albuquerque L.G. 2016. Valores econômicos para sistemas de recria e engorda de bovinos Nelore e cruzado. Arch. Zootec. 65:145-154.

Radostits O.M. 2001. Herd Health: food animal production medicine. W.B. Saunders, Filadélfia, p.456-568.
Rezende A.L., Baptista A.L., Fonseca P.A., Moura R.L., Justo F.B., Nogueira G.M. \& Saut P.E. 2014. Prevalência de doenças em bovinos confinados no município de Paracatu, Minas Gerais. Vet. Notícias 20(1):51.

Rich K.M. \& Perry B.D. 2011. The economic and poverty impacts of animal diseases in developing countries: new roles, new demands for economics and epidemiology. Prev. Vet. Med. 101(3/4):133-147. <http://dx.doi. org/10.1016/j.prevetmed.2010.08.002><PMid:20828844>

Riet-Correa F. 2007. Tétano em bovinos no sul do Rio Grande do Sul: estudo de 24 surtos, p.425-432. In: Riet-Correa F., Schild A.L., Lemos R.A.A. \& Borges J.R.J. (Eds), Doenças de Ruminantes e Equídeos. Vol.1. 3르 ed. Pallotti, Santa Maria.

Rissi D.R., Kommers G.D., Marcolongo-Pereira C., Schild A.L. \& Barros C.S.L. 2010. Meningoencefalite por Listeria monocytogenes em ovinos. Pesq. Vet. Bras. 30(1):51-57. <http://dx.doi.org/10.1590/S0100-736X2010000100008>

Sampaio P.H., Fidelis Junior O.L., Marques L.C. \& Cadioli F.A. 2015. Polioencefalomalacia em ruminantes. Investigação Med. Vet. Unesp 14(2):96-103.

Silva R.O.S., Oliveira Junior C.A., Gonçalves L.A. \& Lobato F.C.F. 2016. Botulism in ruminants in Brazil. Ciência Rural 46(8):1411-1417. <http://dx.doi. org/10.1590/0103-8478cr20151486>

Steinman A., Chaffer M., Elad D. \& Shpigel N.Y. 2006. Quantitative analysis of levels of serum immunoglobulin g against botulinum neurotoxin type $\mathrm{d}$ and association with protection in natural outbreaks of cattle botulism. Clin. Vaccine Immunol. 13(8):862-868. <http://dx.doi.org/10.1128/ CVI.00046-06> <PMid:16893985>

Steinman A., Galon N., Arazi A., Bar-Giora Y. \& Shpigel N.Y.2007. Cattle immune response to botulinum type $D$ toxoid: results of a vaccination study. Vaccine 25(44):7636-7640. <http://dx.doi.org/10.1016/j.vaccine.2007.08.051> <PMid:17913314>

Tavella A., Morosetti G., Caresia S., Ciavatta P., Trevisiol K., Armani M.C., Stifter E., Piffer C., Bano L. \& Lombardo D. 2014. Acute Type C botulism with fatal consequences in a Holstein Breeding establishment in northern Italy. J. Vet. Sci. Anim. Husb. 5:502-506.

WHO 2002. Clostridium botulinum: international programme on chemical safety poisons information. Monograph 858 Bacteria. Available at $<\mathrm{http}$ ://www.who. int/csr/delibepidemics/clostridiumbotulism.pdf> Access on Dec. 20, 2017. 